J. Biosci., Vol. 3 Number 2, June 1981, pp. 179-190. (C) Printed in India.

\title{
Allosteric serine hydroxymethyltransferase from monkey liver: temperature induced conformational transitions
}

\author{
KASHI S. RAMESH*, V. S. ANANTHANARAYANAN** and N. APPAJI \\ RAO \\ Department of Biochemistry, Indian Institute of Science, Bangalore 560012 \\ **Department of Biochemistry, Memorial University of Newfoundland, St. John's, \\ Newfoundland, Canada A1B 3X9. \\ MS received 11 February 1981
}

\begin{abstract}
The homogeneous serine hydroxymethyltransferase from monkey liver was optimally activate at $60^{\circ} \mathrm{C}$ and the Arrhenius plot for the enzyme was nonlinear with a break at $15^{\circ} \mathrm{C}$. The monkey liver enzyme showed high thermal stability of $62^{\circ} \mathrm{C}$, as monitored by circular dichroism at $222 \mathrm{~nm}$, absorbance at $280 \mathrm{~nm}$ and enzyme activity. The enzyme exhibited a sharp co-operative thermal transition in the range of $50^{\circ}-70^{\circ}\left(T_{m}=65^{\circ} \mathrm{C}\right)$, as monitored by circular dichroism. L-Serine protected the enzyme against both thermal inactivation and thermal disruption of the secondary structure. The homotropic interactions of tetrahydrofolate with the enzyme was abolished at high temperatures (at $70^{\circ} \mathrm{C}$, the Hill coefficient value was 1.0). A plot of $h$ values vs. assay temperature of tetrahydrofolate saturation experiments, showed the presence of an intermediate conformer with an $h$ value of 1.7 in the temperature range of $45^{\circ}-60^{\circ} \mathrm{C}$. Inclusion of a heat denaturation step in the scheme employed for the purification of serine hydroxymethyltransferase resulted in the loss of cooperative interactions with tetrahydrofolate. The temperature effects on the serine hydroxylmethyltransferase, reported for the first time, lead to a better understanding of the heat induced alterations in conformation and activity for this oligomeric protein.
\end{abstract}

Keywords. Serine hydroxymethyltransferase; circular dichroism; thermal stability; conformational transitions.

\section{Introduction}

The kinetic, regulatory, physicochemical, immunological studies (Ramesh, 1979, 1980; Ramesh and Appaji Rao, 1978, 1980a, 1980b) and the investigation on the denaturation (Ramesh et al., 1980), suggested that the oligomeric serine hydroxylmethyltransferase from monkey liver exhibited conformational fluctuations consequent to the binding of effectors, ligands and change in the solution environment. It was quite surprising to note that the temperature-dependence of the reaction

\footnotetext{
Abbreviations used: c.d., circular dichroism; u.v., ultraviolet; $[\theta]_{\text {m.r.w., }}$ mean residue ellipticity; $\mathrm{H}_{4}$ folate, (+)-L-tetrahydrofolate; dimedone, 5,5-dimethylcyclohexane-1, 3-dione.

* Present Address: Hematology Research Laboratory, Massachusetts General Hospital, Harvard Medical School, Boston, Massachusetts, USA.
} 
catalyzed by serine hydroxymethyltransferase from any source had not been reported, although heat inactivation of contaminating proteins in the presence of L-serine has been used as a major step in the purification of this enzyme from several sources (Nakano et al., 1980; Fujioka, 1969; Rowe and Lewis, 1973; Jones and Priest, 1976). An earlier report from this laboratory showed that this enzyme from monkey liver isolated without the heat-denaturation step, exhibited both homotropic and heterotropic co-operative interactions (Ramesh and Appaji Rao 1980b). It was therefore of interest to examine the nature of the temperatureinduced effects on the protein. These temperature-induced transitions, monitored using spectroscopic and kinetic methods, are described in this paper.

\section{Materials and methods}

\section{Materials}

DL- $\left[3^{-14} \mathrm{C}\right]$ Serine (specific activity $48.5 \mathrm{mCi} / \mathrm{mmol}$ ) was obtained from $\mathrm{New}$ England Nuclear (Boston, Massachussets, USA). $\mathrm{H}_{4}$ folate prepared by the method of Hatefi et al. (1960), was generously given by Dr. John H. Mangum (Brigham Young University, Provo, Utah, USA) . Pyridoxal 5'-phosphate, EDTA, and 2-mercaptoethanol were products of Sigma Chemical Co. (St. Louis, Missouri, USA).

\section{Methods}

Serine hydroxymethyltransferase from monkey liver was purified as described earlier (Ramesh, 1979; Ramesh and Appaji Rao, 1980b). The enzyme was assayed by a radiochemical method (Taylor and Weissbach, 1965) using DL- $\left[3^{-14} \mathrm{C}\right]$ serine as the substrate; and the amount of $\left[{ }^{14} \mathrm{C}\right]$ formaldehyde formed in 15 min was estimated (Ramesh and Appaji Rao, 1978). One unit of enzyme activity was defined as the amount that catalyzed the formation of $1 \mu \mathrm{mol}$ of formaldehyde/min at $37^{\circ} \mathrm{C}, \mathrm{pH}$ 7.4. Protein concentration was determined by the method of Lowry et al. (1951) with bovine serum albumin as the standard.

Circular dichroic measurements were performed on a Jasco-20 scanning spectropolarimeter. The circular dichrometer was calibrated using an aqueous solution of d-10-camphor sulphonic acid (Cassim and Young, 1969). All buffers, reagents and enzyme solutions were passed through Millipore filters (HA $0.45 \mu \mathrm{m}$ ) before recording the c.d. spectra. The spectropolarimeter was continuously purged with pre-purified nitrogen before and during the experiments. All the c.d. spectra were recorded with the slit programmed for $1 \mathrm{~nm}$-spectral band width, a chart speed of 4 $\mathrm{nm} / \mathrm{min}$, a time constant of $64 \mathrm{~s}$ and a wavelength expansion of $5 \mathrm{~nm} / \mathrm{cm}$.

Temperature effects were studied in jacketed cells through which an ethylene glycol-water mixture was circulated from a thermostatically controlled water circular bath. The temperature of the sample was increased in a stepwise manner at a constant rate. Temperature was measured in the cell holder by making use of the mercury contact. A quartz cell of $1 \mathrm{~nm}$-pathlength was used in melting-profile 
experiments. All c.d. spectral data were plotted as mean residue ellipticity 0, and was calculated using the formula:

$$
[0]_{\text {m.r.w. }}=(\theta \times \text { m.r.w. }) /(10 \times l \times c)
$$

and expressed in units of degree $\mathrm{cm}^{2} \cdot \mathrm{dmol}^{-1}$; where 0 is the observed ellipticity in degrees, m.r.w. is the mean residue weight (assumed to be 115), $l$ is the optical pathlength in $\mathrm{cm}$ and $c$ is the concentration of the enzyme in $\mathrm{g} / \mathrm{ml}$.

\section{Results}

Effect of temperature on the velocity of the reaction catalyzed by monkey liver serine hydroxymethyltransferase

Arrhenius plot of $\log v$ (velocity at saturating concentration of substrates) vs. the reciprocal of absolute temperature $(T)$ and a plot of $v$ vs. the temperature $\left({ }^{\circ} \mathrm{C}\right)$ are shown in figure 1 . The inset plot shows $60^{\circ} \mathrm{C}$ as the optimal temperature for the

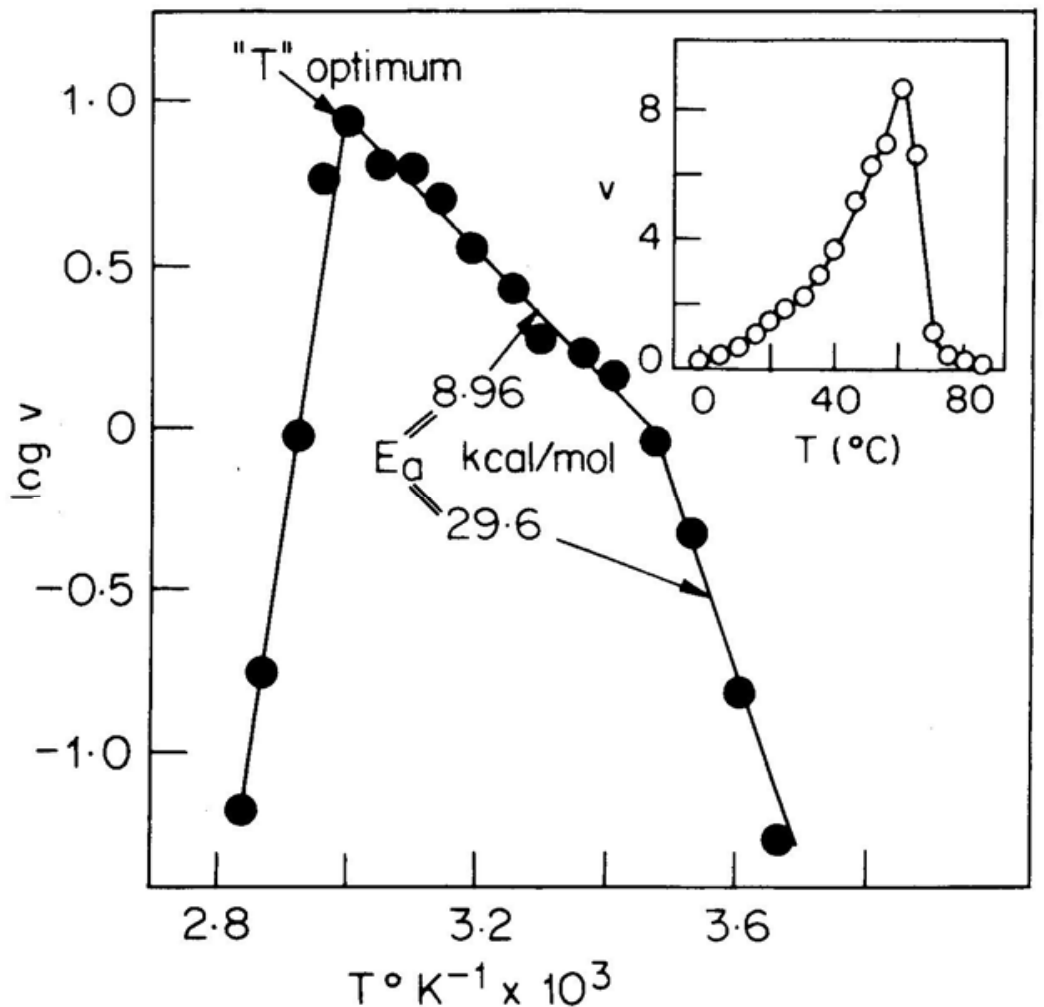

Figure 1. Arrhenius plot for the monkey liver serine hydroxymethyltransferase. The activity of the enzyme $(1.1 \mu \mathrm{g}$ in $50 \mathrm{mM}$ potassium phosphate buffer, $\mathrm{pH}$ 7.4) was assayed at different fixed temperature $\left(0-80^{\circ} \mathrm{C}\right)$ in the presence of saturating concentrations of L-serine $(3.6 \mathrm{mM})$ and $\mathrm{H}_{4}$ folate $(1.8 \mathrm{mM})$. The $\mathrm{H}_{4}$ folate concentration was increased to $2.1 \mathrm{mM}$, when the enzyme activity was measured above $50^{\circ} \mathrm{C}$. This was to ensure that saturating concentrations of the substrates were present at all temperatures. The inset shows the plot of initial velocity vs. temperature of the assay in degrees centigrade. 
reaction catalyzed by serine hydroxymethyltransferase. The Arrhenius plot showed a linear increase between $0^{\circ} \mathrm{C}$ to $60^{\circ} \mathrm{C}$ with a break at $15^{\circ} \mathrm{C}$. Activation energies $\left(E_{a}\right)$ calculated from the slopes in figure 1 , were $29.6 \mathrm{~K} \mathrm{cal} \mathrm{mol}{ }^{-1}\left(0-15^{\circ} \mathrm{C}\right)$ and $9 \mathrm{~K}$ cal $\mathrm{mol}^{-1}\left(15-60^{\circ} \mathrm{C}\right)$. The velocity decreased rapidly at higher temperatures $\left(>62^{\circ} \mathrm{C}\right)$ due to inactivation of the enzyme.

\section{Thermal stability}

The thermal stability was monitored by measuring enzyme activity, the absorbance at $280 \mathrm{~nm}$ and the c.d. spectrum in the region, 200-250 nm. In these experiments, the enzyme was heated at different temperatures and for different time intervals and quickly cooled to $0^{\circ} \mathrm{C}$. The enzyme activity and the spectral properties were measured at $37^{\circ} \mathrm{C}$ and $25^{\circ} \mathrm{C}$, respectively.

It is evident from figure 2 that the enzyme was stable at $50^{\circ} \mathrm{C}$ for $20 \mathrm{~min}$. At $65^{\circ} \mathrm{C}$, there was a progressive loss of enzyme activity with increasing periods of heating. However, at $70^{\circ} \mathrm{C}$, the enzyme was rapidly inactivated, with complete loss of activity occurring in $6 \mathrm{~min}$. Similar denaturation profiles were obtained when the enzyme concentration was increased from $100 \mu \mathrm{g}$ to $1 \mathrm{mg} / 400 \mu \mathrm{l}$ buffer; suggesting that the rate of thermal inactivation was not dependent on the concentration of the enzyme.

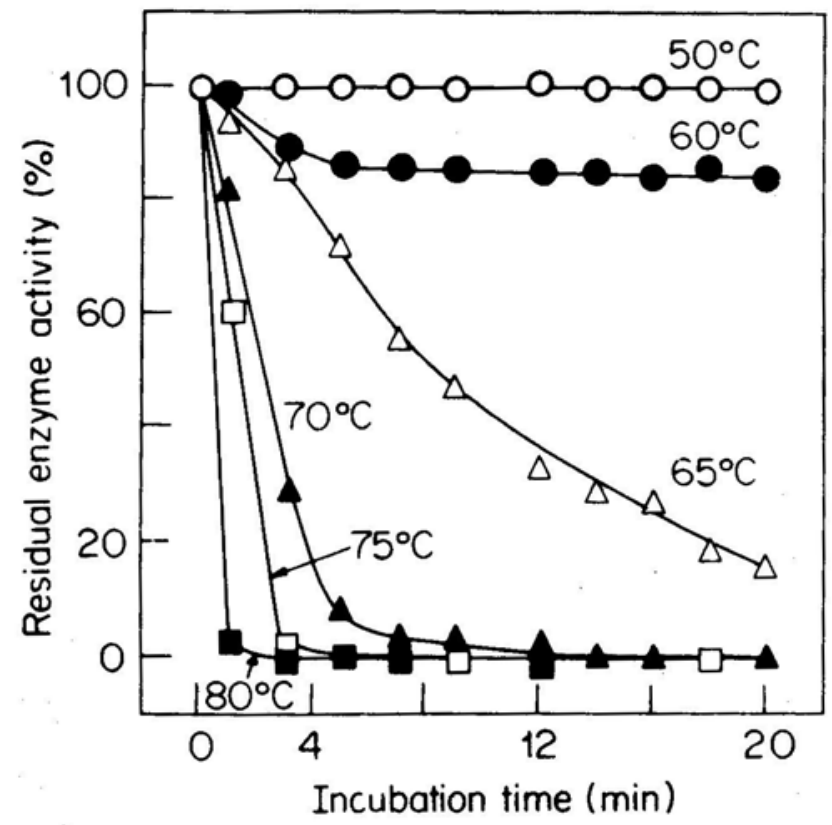

Figure 2. Thermal stability: Effect of pre-incubation temperature on the enzyme activity. The enzyme $(100 \mu \mathrm{g} / 400 \mu \mathrm{l}$ of $50 \mathrm{mM}$-potassium phosphate buffer, $\mathrm{pH}$ 7.4) was heated at different temperatures $\left(50^{\circ}-80^{\circ} \mathrm{C}\right)$ and aliquots were withdrawn at the time intervals indicated in the figure. The aliquots were cooled in ice. All the samples were warmed to $37^{\circ} \mathrm{C}$ by incubating for $5 \mathrm{~min}$ in a water-bath and the enzyme assayed at $37^{\circ} \mathrm{C}$. The activity of a control sample maintained at $37^{\circ} \mathrm{C}$ was normalized to 100 . The results of the experiment are expressed as per cent of the activity of unheated controls. 
Figure 3 shows the family of far-u.v. c.d. spectral curves observed on increasing the temperature from $25^{\circ}$ to $70^{\circ} \mathrm{C}$. The prominent features of the helix relatedc.d. spectrum remained unperturbed upto $50^{\circ} \mathrm{C}$. Above $50^{\circ} \mathrm{C}$, the amplitudes of the c.d. spectral bands decreased and at $67^{\circ} \mathrm{C}$, the spectrum observed was consistent with that of a largely unfolded polypeptide chain.

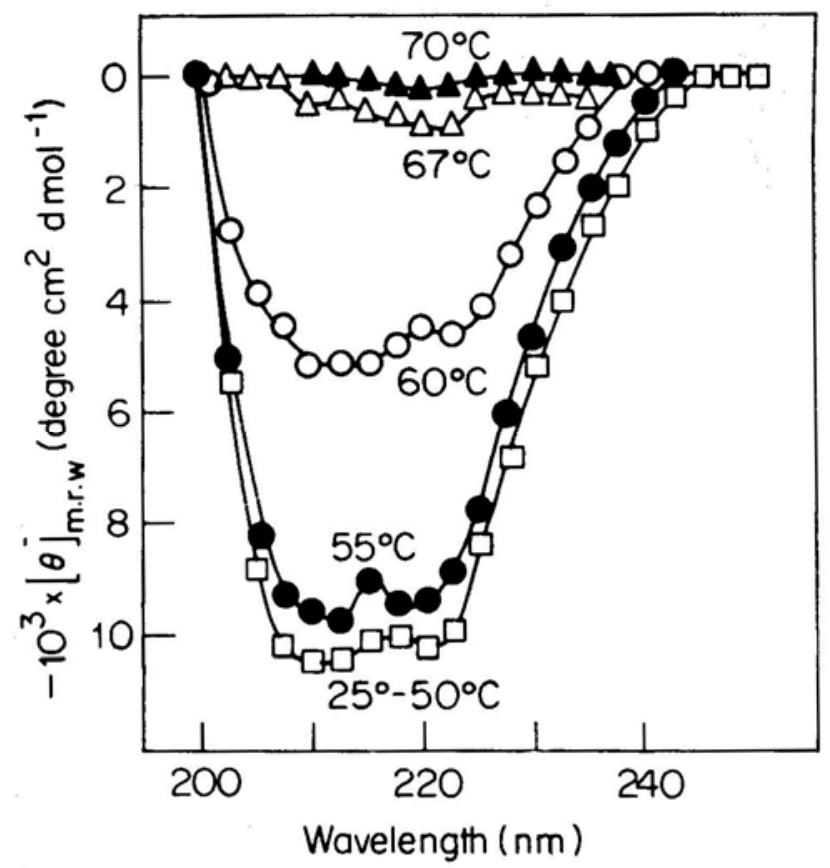

Figure 3. Thermal stability: Effect of pre-incubation temperature on the far u.v. circular dichroic spectra of the enzyme. The enzyme $(270 \mu \mathrm{g} / \mathrm{ml})$ was heated at different temperature $\left(25^{\circ}-70^{\circ} \mathrm{C}\right)$ for $10 \mathrm{~min}$ and immediately chilled in ice. C.d. spectra were recorded at $25^{\circ} \mathrm{C}$ using a demountable quartz cell of $0.5 \mathrm{~mm}$-light path. Above $65^{\circ} \mathrm{C}$, the enzyme solution became slightly turbid and these samples were centrifuged before recording the c.d. spectra.

Figure 4 summarizes the relationship obtained between (i) ${ }^{-}[\theta]_{222}$, a sensitive parameter of polypeptide backbone conformation, (ii) $A_{280}$ a parameter related to tertiary structure of the protein, and (iii) enzyme activity, a parameter related to structural integrity of the active site, and the preincubation temperature. As can be seen from the figure, there was no decrease of either the activity or the $[\theta]_{222}$ or $A_{280}$ values upto $52^{\circ} \mathrm{C}$. Above this temperature, there was a sharp and parallel decrease in these parameters indicative of a major conformational change. The mid-points of the unfolding transition calculated from these curves are around $62^{\circ} \mathrm{C}$.

\section{Thermal melting profile}

The melting-profile of the enzyme was determined by continuously monitoring the c.d. signal at $222 \mathrm{~nm}$ in the temperatue range of $10^{\circ}-85^{\circ} \mathrm{C}$. Figure 5 shows the temperature dependence of the mean residue ellipticity, [ $\theta$ ] at $222 \mathrm{~nm}$, with a sharp 


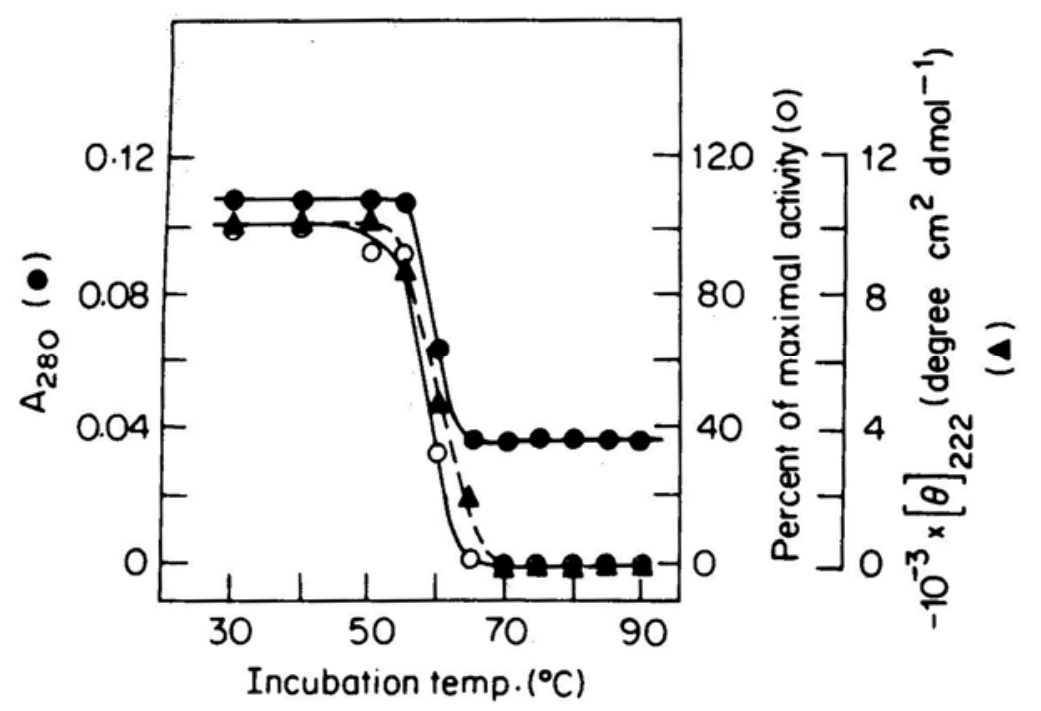

Figure 4. Effect of preincubation temperature on the structure $\left(\mathrm{A}_{280}\right.$ and $\left.-[\theta]_{222}\right)$ and enzyme activity. The enzyme $(270 \mu \mathrm{g} / \mathrm{ml})$ was heated at different temperatures $\left(30^{\circ}-90^{\circ} \mathrm{C}\right)$ for $10 \mathrm{~min}$ and immediately chilled in ice. The sample was used to measure the $-[\theta]_{222}$ value $(\Delta), \mathrm{A}_{280}(\mathrm{O})$ at $25^{\circ} \mathrm{C}$ and enzyme activity at $37^{\circ} \mathrm{C}(\mathrm{O})$. Activity of the unheated enzyme was normalized to 100 .

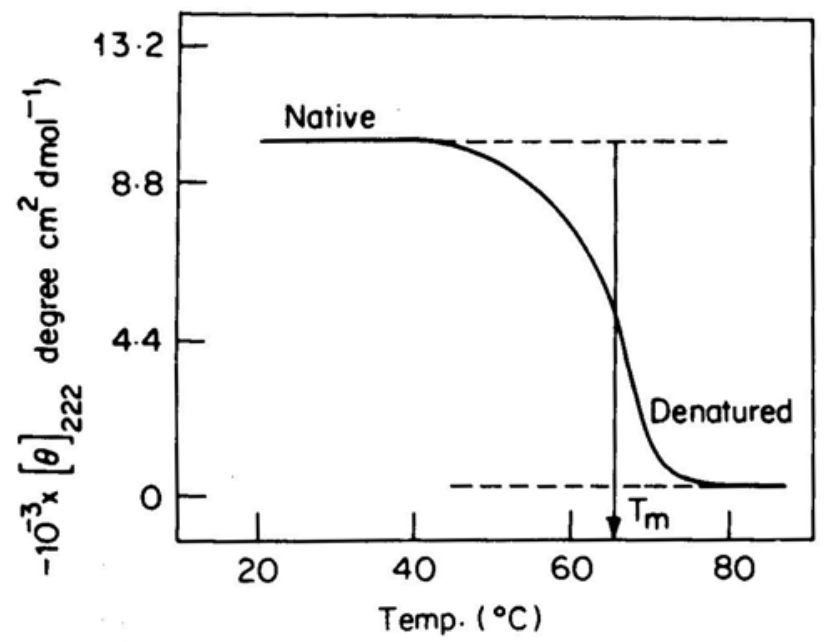

Figure 5. The thermal melting profile. A quartz cell of $1 \mathrm{~mm}$ path length and a protein concentration of $0.5 \mathrm{mg} / \mathrm{ml}$ were used to monitor the c. d. signals at $222 \mathrm{~nm}$. It was ascertained that no significant changes in the concentration of the enzyme occurred at high temperatures due to evaporation, by tightly closing the cell with a cap and parafilm. The temperature of the enzyme solution in the cell was gradually increased in a step-wise manner from $20^{\circ}$ to $85^{\circ} \mathrm{C}$. The circular dichroic signals were recorded after equilibrating the cell for at least $10 \mathrm{~min}$, after each desired temperature was attained. 
co-operative thermal transition in the range of $50^{\circ}-70^{\circ} \mathrm{C}$. A melting temperature ( $T_{m}$, defined as the temperature at which the melting-profile crosses the mid-point between the two values extrapolated from the native and the denatured region of the macromolecule) of $65^{\circ} \mathrm{C}$ was observed. When the enzyme was heated at temperatures above $50^{\circ} \mathrm{C}$, cooled and $[\theta]_{222}$ values determined, the values obtained were identical to those observed at the corresponding elevated temperatures.

\section{Effect of substrates on the thermal stability of the enzyme}

The susceptibility of the enzyme to thermal inactivation in the absence and in the presence of added substrates is shown in figure 6. In the absence of any substrate,

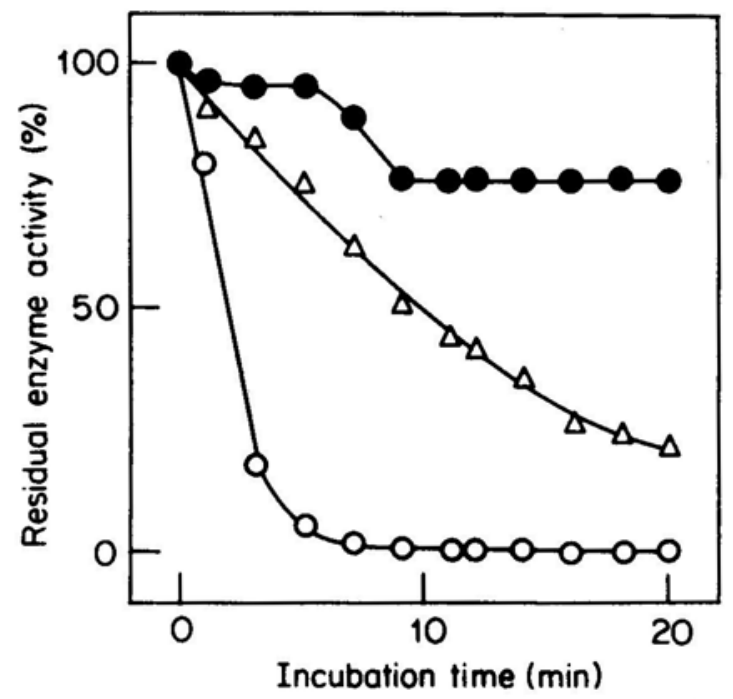

Figure 6. Heat-inactivation patterns of the enzyme in the presence of L-serine and $\mathrm{H}_{4}$ folate The enzyme $(100 \mu \mathrm{g} / 400 \mu /$ of $50 \mathrm{mM}$ potassium phosphate buffer, $\mathrm{pH} 7.4)$ in the presence of $18 \mathrm{mM}$ L-serine $(\bullet), 9 \mathrm{mM} \mathrm{H}$ folate $(\Delta)$ and enzyme alone $(\mathrm{O})$ was heated at $70^{\circ} \mathrm{C}$. Aliquots were removed at definite time intervals and the thermal inactivation of the enzyme was terminated by chilling them in ice. The enzyme activity was assayed at $37^{\circ} \mathrm{C}$. The enzyme activity of the sample which was not subjected to heat treatment was normalized to 100 .

the enzyme lost its activity within 6-7 $\mathrm{min}$ on heating at $70^{\circ} \mathrm{C}$. However, in the presence of L-serine $(18 \mathrm{mM})$, there was only slight inactivation $(<2 \%)$ within a $5 \mathrm{~min}$ period and at $10 \mathrm{~min}, 20 \%$ inactivation of the enzyme occurred. After this time, there was no further loss of activity upto $20 \mathrm{~min}$. Addition of $\mathrm{H}_{4}$ folate to the enzyme prior to heating at $70^{\circ} \mathrm{C}$, did not result in significant protection of the enzyme from inactivation. NADH and NADPH (allosteric activators, upto 10 $\mathrm{mM}$ ) exerted no significant influence on the thermal inactivation of the enzyme at $70^{\circ} \mathrm{C}$.

To understand the relationship between the observed structural transition and the catalytic function, circular dichroism was used in order to confirm the presence of conformational transition in the enzyme which exhibited substrate-induced 
thermal stability (Ramesh and Appaji Rao 1980b). As can be seen in figure 7, the c.d. spectrum of the enzyme heated at $70^{\circ} \mathrm{C}(10 \mathrm{~min})$ in the presence of L-serine $(18$ $\mathrm{mM}$ ) showed significant $\mathrm{c}$ d. ellipticitybands at 221 and $208 \mathrm{~nm}$, as compared to the c.d. spectrum of the enzyme obtained on heating at $70^{\circ} \mathrm{C}$ without the addition of Lserine. The latter spectrum indicated the absence of even the traces of secondary structure in the enzyme. For comparison, the spectrum of the enzyme, which was not subjected to heating at $70^{\circ} \mathrm{C}$ is shown in figure 7 .

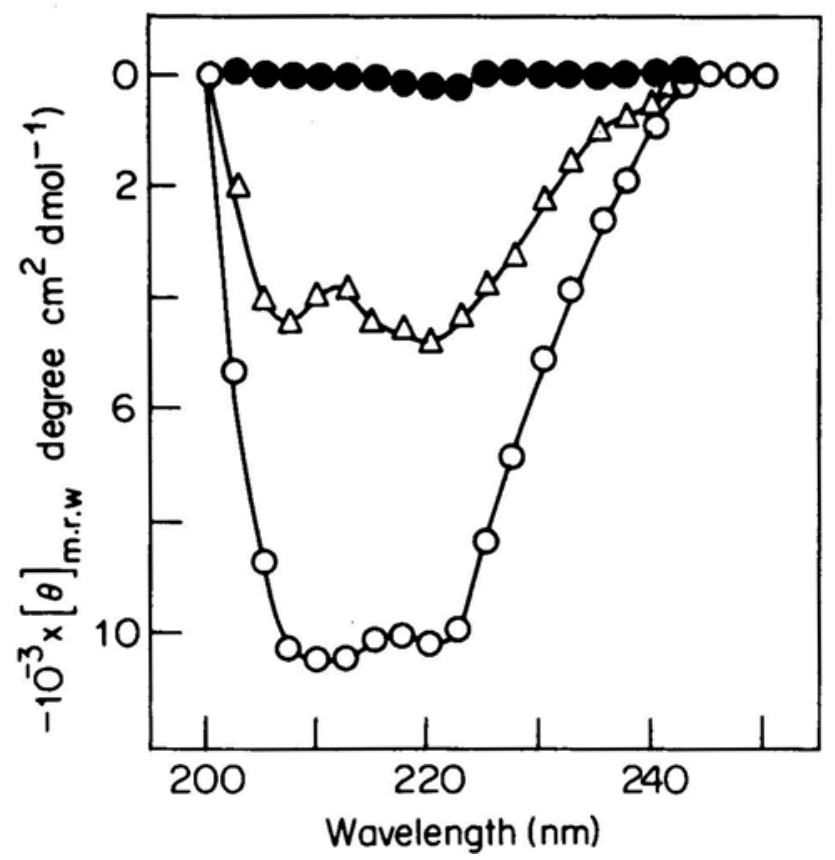

Figure 7. Protective effect of L-serine against temperature-induced loss of circular dichroic properties of the enzyme. The enzyme $(270 \mu \mathrm{g} / \mathrm{ml})$ was heated for $10 \mathrm{~min}$ at $70^{\circ} \mathrm{C}$ in the absence $(\bullet)$ and in the presence $(\Delta)$ of $18 \mathrm{mM}$ L-serine. The sample was immediately chilled in ice and the c.d. spectra recorded at $25^{\circ} \mathrm{C}$ using a $0.5 \mathrm{~mm}$ light path demountable quartz cell. For comparison, the spectrum of the enzyme which was not heated at $70^{\circ} \mathrm{C}$ is shown $(\mathrm{O})$.

Effect of temperature on the positive homotropic interaction of $\mathrm{H}_{4}$ folate (i.e.,Hill coefficient, $h$ ) with the enzyme

Figure 8 depicts the $h$ values plotted vs. incubation temperature. It is evident from the figure that the $h$ value of 2.5 was not altered upto $38^{\circ} \mathrm{C}$ and above this temperature there was a rapid decrease in the $h$ value upto $45^{\circ} \mathrm{C}(h=1.7)$. The $h$ value of 1.7 remained constant upto $60^{\circ} \mathrm{C}$ and above this temperature there was a further decline in the $h$ value; at $70^{\circ} \mathrm{C}$, the Hill coefficient reached a value of 1.0. The $\mathrm{H}_{4}$ folate saturation curve at $70^{\circ} \mathrm{C}$ was hyperbolic and the Lineweaver-Burk plot was linear.

The enzyme purified using heat denaturation step $\left(70^{\circ} \mathrm{C}, 5 \mathrm{~min}\right)$ failed to exhibit positive homotropic co-operative interactions with $\mathrm{H}_{4}$ folate. This is indicated by a hyperbolic saturation pattern (figure 9) with a Hill coefficient $(h)$ value of 1.1 (inset to figure 9). 


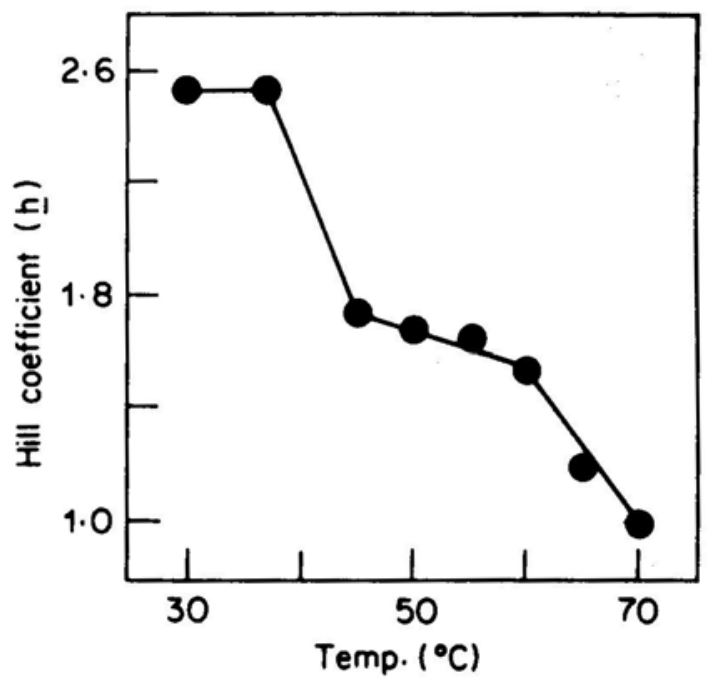

Figure 8. Effect of temperature on the Hill coefficient of H4folate saturation of the enzyme The enzyme $(1 \mu \mathrm{g})$ was preincubated with different concentrations of $\mathrm{H}_{4}$ folate $(0.036-2.2$ $\mathrm{mM}$ ) for $5 \mathrm{~min}$ and then for $15 \mathrm{~min}$ with $3.6 \mathrm{mM} \mathrm{L}-\left[3^{-14} \mathrm{C}\right]$ serine at different fixed temperatures $\left(30^{\circ}-70^{\circ} \mathrm{C}\right)$. After terminating the reaction by the addition of dimedone, the amount of $\left[{ }^{14} \mathrm{C}\right]$ formaldehyde formed was estimated (Ramesh and Appaji Rao, 1978). The Hill coefficient $(h)$ was calculated from a Hill plot of the $\mathrm{H}_{4}$ folate saturation, curve at each temperature (Segel, 1975).

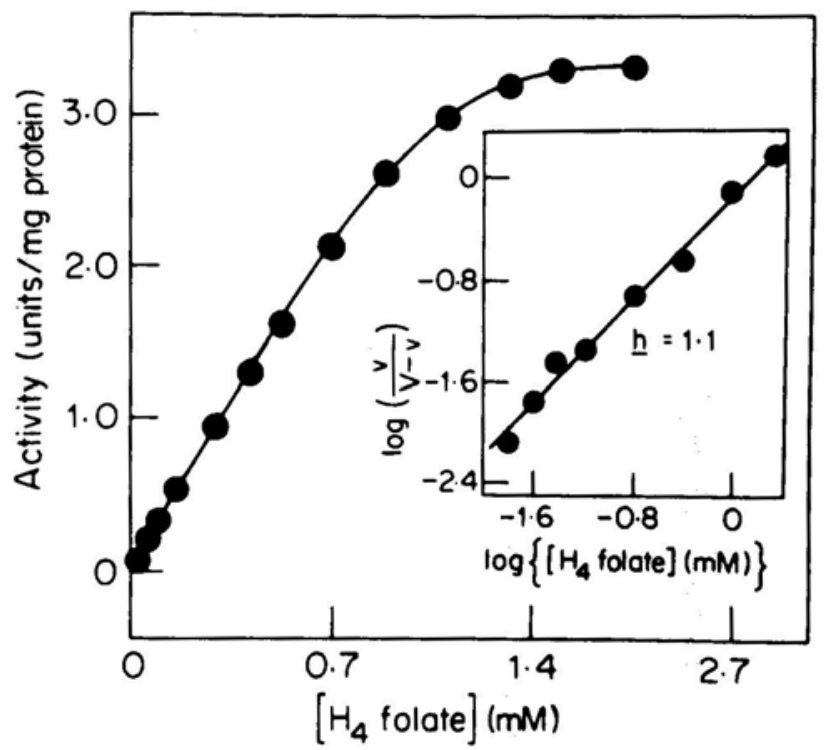

Figure 9. $\mathrm{H}_{4}$ folate saturation pattern of the enzyme purified using heat denaturation step. The enzyme from monkey liver was purified by heating the crude extract for 5 min at $70^{\circ} \mathrm{C}$, followed by $\left(\mathrm{NH}_{4}\right)_{2} \mathrm{SO}_{4}$ fractionation, CM-Sephadex chromatography, ultrogel-ACA34 gel filtration and Blue Sepharose CL-6B affinity chromatography (Ramesh \& Appaji Rao, 1980b). This enzyme preparation was used for the $\mathrm{H}_{4}$ folate saturation experiment (for details see Ramesh and Appaji Rao, 1978). The inset shows the Hill plot of the data obtained. 


\section{Discussion}

Thermally induced conformational transitions have been accepted as explanations for the temperature dependence of a number of properties of macromolecules (Massey et al., 1966; Berman and Boyer, 1972; Kelley and Von Hippel, 1976; Zav'yalov et al., 1977; Sturtevant and Matco, 1978; Fujita et al., 1979; Matheson and Scheraga, 1979a, b; Ralston and Dunbar, 1979; Vita et al., 1979 Ugarovo et al., 1979; Luer and Wong, 1980) and have helped in the understanding of the forces that stabilize the higher order structure of proteins and of protein-ligand interactions. The Arrhenius plot for the monkey liver serine hydroxymethyltransferase showed a biphasic curve, with a break at $15^{\circ} \mathrm{C}$ (figure 1) suggesting temperature-induced conformational change in the molecule. Non-linear Arrhenius plots similar to that observed in the present study have been reported for a few proteins (Sizer, 1943; Levy et al., 1959; Massey et al., 1966; Saint-Blancard et al., 1977; Matheson and Scheraga, 1979b; Berge et al., 1980) and have been interpreted to suggest temperature induced conformational changes. Before invoking this, possibilities such as (i) phase change in the solvent, (ii) failure to maintain saturation of the enzyme with the substrates at elevated temperatures, (iii) artifacts of mixing, (iv) reversible enzyme inactivation, and (v) buffer effects have to be ruled out (Dixon and Webb, 1958). These have been carefully considered and ruled out before invoking conformational change in the enzyme. Thus the nonlinear Arrhenius plot provides evidence in favour of the existence of non-denaturational transitions and also illustrates the concept of limited molecular rearrangement as a possible mechanism for metabolic regulation.

Temperature induced transitions in the enzyme structure are evident from the changes in $A_{280}$ which is indicative of alterations in the tertiary structure; ${ }^{-}[\theta]_{222}$ values, which are correlated to secondary structure of the protein; and the loss of enzyme activity reflecting alterations in the catalytic site (figure 4). By using thermal unfolding as a sensitive probe to measure changes in the different orders of structural organization in the enzyme molecule, it was found that the loss of enzyme activity, and the decrease in $A_{280}$ and $-[\theta]_{222}$ values followed a similar pattern suggesting that these properties are closely related. A similar $T_{m}\left(62^{\circ} \mathrm{C}\right)$ value was obtained, for all the parameters plotted as a function of pre-incubation temperature. A similarity of the melting profiles and the occurrence of an identical $T_{m}$ value for different conformational probes have been used as evidence for a two-state co-operative unfolding process, without observable intermediates (Lumry et al., 1966).

The changes in $-[\theta]_{222}$ values displayed a sigmoidal dependence on the temperature (figure 5) in the range of $50^{\circ}-70^{\circ} \mathrm{C}$. A $T_{m}$ value of $65^{\circ} \mathrm{C}$ was calculated from this curve. It was also seen that in the region of the major thermal transition $\left(50^{\circ}\right.$ $70^{\circ} \mathrm{C}$ ), no evidence for intermediates were found. These results are compatible with the hypothesis that two-state co-operative transitions occur during the thermal denaturation of monkey liver serine hydroxymethyltransferase. However, this can be confirmed only after performing precise differential scanning microcalorimetric studies and fast reaction temperature-jump experiments. 
The binding of L-serine to the enzyme confers significant thermal stability to the enzyme, whereas $\mathrm{H}_{4}$ folate affords only meagre protection against thermal inactivation (figure 6). These results suggest that the binding of L-serine promotes a conformational change in the native enzyme to a thermostable conformer and this conclusion has been supported by circular dichroism studies (figure 7). Ligand induced stabilization against heat inactivation may also be explained by invoking protection by the substrate of heat labile groups at or near the active site on the enzyme molecule. Similar explanations for substrate protection have been given by several workers (Grisolia and Joyce, 1960; Segel et al., 1968; Theorell and Tatemoto, 1971; Citri, 1973).

At high temperatures, above $65^{\circ} \mathrm{C}$, the $\mathrm{H}_{4}$ folate saturation curve became hyperbolic, as indicated by a Hill coefficient value of 1.0 (figure 8). In other words, the homotropic co-operative interactions of $\mathrm{H}_{4}$ folate with the enzyme was abolished at high temperatures. At temperatures above $60^{\circ} \mathrm{C}$, the critical interaction between subunits seems to have been lost. These results are further confirmed by desensitization of the enzyme using a heat step during the purification (figure 9). Although the studies on the effect of temperature on the structure of the enzyme clearly indicated the absence of intermediates in the process of denaturation (as monitored by c.d., $A_{280}$, and enzyme activity), the effect of temperature on the Hill coefficient for the interaction of $\mathrm{H}_{4}$ folate with the enzyme, showed the presence of an intermediate conformer with an $h$ value of 1.7. The mol. wt of the native as well as the temperature desensitized enzyme were identical indicating that dissociation of the enzyme may not have occurred at elevated temperatures (data not given). These results would suggest that intermediate conformations are possible during the process of thermal denaturation. The apparent discrepancy in the results obtained by spectroscopic methods and the kinetic methods, may be due to the differences in the sensitivity of these two probes.

In conclusion, the results presented in this paper suggest that temperature induced conformational changes may have a role in the metabolic regulation of serine hydroxymethyltransferase.

\section{Acknowledgements}

This investigation was supported by a research grant from the Department of Science and Technology, Government of India, New Delhi. We thank Professor A. Salahuddin (Protein Research Laboratory, Aligarh Muslim University, Aligarh) for his valuable suggestions and discussions and Dr. M. W. Pandit (Centre for Cellular and Molecular Biology, Regional Research Laboratory, Hyderabad) for permitting the use of Jasco-20 spectropolarimeter. K.S.R. is the recipient of a Senior Research Fellowship of the Department of Atomic Energy, Government of India, Bombay.

\section{References}

Berge, R. K., Slinde, E. and Farstad, M. (1980) FEBS Lett., 109, 194.

Berman, K. and Boyer, P. D. (1972) Biochemistry, 11, 4650.

Cassim, J. Y. and Yang, J. T. (1969) Biochemistry., 8, 1947.

Citri, N. (1973) Adv. Enzymol., 37, 397.

Dixon, M. and Webb, E. C. (1958) Enzymes 1st ed., pp. 158. 
Fujioka, M. (1969) Biochim. Biophys. Acta, 185, 338.

Fujita, 5. C. Go, N. and Imahori, K. (1979) Biochemistry, 18, 24.

Grisolia, S. and Joyce, B. K. (1960) Biochem. Pharmacol., 3, 167.

Hatefi, Y., Talbert, P. T., Osborn, M. J. and Huennekens, F. M, (1960) Biochem. Prep., 7, 89.

Jones, C. W. and Priest, D. G. (1976) Arch. Biochem. Biophys., 174, 305.

Kelly, R. C. and Von Hippel, P. H. (1976) J. Biol. Chem., 251, 7229.

Levy, H. M., Sharon, N. and Koshland, D. E. (1959) Biochim. Biophys Acta, 33, 288.

Lowry, O. H., Rosebrough, N. J., Farr, A. L. and Randall, R. J. (1951) J. Biol. Chem., 193, 265.

Luer, C A. and Wong, K. P. (1980) Biochemistry, 19,176.

Lumry, R., Biltonen, R. and Brandts, J. F. (1966) Biopolymers, 4, 917.

Massey, V., Curti, B. and Ganther, H. (1966) J. Biol. Chem., 241, 2347.

Matheson, Jr., R. R. and Scheraga, H. A. (1979a) Biochemistry, 18, 2437.

Matheson, Jr., R. R. and Scheraga, H. A. (1979b) Biochemistry, 18, 2446.

Nakano, Y., Fujioka, M. and Wada, H. (1968) Biochim. Biophys. Acta, 159, 19.

Ralston; G. B. and Dunbar, J. C. (1979) Biochim. Biophys. Acta, 579, 20.

Ramesh, K. S. (1979) Indian J. Biochem. Biophys., 16, 77.

Ramesh, K. S. (1980) Serine Hydroxymethyltransferase from Monkey Liver: Biochemical, Regulatory, Immunokinetic and Conformational Studies, Ph.D. Thesis, Indian Institute of Science, Bangalore, India.

Ramesh, K. S. and Appaji Rao, N. (1978) Biochem. J., 174, 1055.

Ramesh, K. S. and Appaji Rao, N. (1980a) Biochem. J., 187, 249.

Ramesh, K. S. and Appaji Rao, N. (1980b) Biochem. J., 187, 623.

Ramesh, K. S., Ananthanarayanan, V. S. and Appaji Rao, N. (1980) J. Biosci., 3,

Rowe, P. B. and Lewis, G. P. (1973) Biochemistry, 12, 1962.

Saint-Blancard, J., Clochard, A., Cozzone, P., Berthou, J. and Jolles, P. (1977) Biochim. Biophys. Acta 491, 354.

Segel, I. H. (1975) Enzyme Kinetics, (New York: John Wiley) p. 371.

Segel, H. L., Abraham, G. J. and Matsuzawa, T. (1968) Biochem. Biophys. Res. Commun., 30, 63.

Sizer, I. W. (1943) Adv. Enzymol., 3, 35.

Sturtevant, J. M. and Mateo, P. L. (1978) Proc. Natl. Acad. Sci. U.S.A., 75, 2584.

Taylor, R. T. and Weissbach, H. (1965) Anal. Biochem., 13, 80.

Theorell, H. and Tatemoto, K. (1971) Arch. Biochem. Biophys., 143, 354.

Ugarova, N. N., Rozhkova, G. D. and Berezin, I. V. (1979) Biochim. Biophys. Acta, 570, 31.

Vita, C, Fontana, A., Seeman, J. R. and Chaiken, I. M. (1979) Biochemistry, 18, 3023.

Zav'yalov, V. P., Demchenko, A. P., Suchomudrenko, A. G. and Troitsky, G. V. (1977)Biochim Biophys Acta, 491, 7. 